\title{
Re-election Concerns and the Failure of Plea Bargaining
}

\author{
Siddhartha Bandyopadhyay ${ }^{1}$, Bryan C. McCannon ${ }^{2}$ \\ ${ }^{1}$ University of Birmingham, Birmingham, United Kingdom \\ ${ }^{2}$ St. Bonaventure University, New York, USA \\ Email: s.bandyopadhyay@bham.ac.uk
}

Received July 31, 2013; revised: August 30, 2013; accepted September 9, 2013

Copyright (C) 2013 Siddhartha Bandyopadhyay, Bryan C. McCannon. This is an open access article distributed under the Creative Commons Attribution License, which permits unrestricted use, distribution, and reproduction in any medium, provided the original work is properly cited.

\begin{abstract}
In this note, we provide a new explanation for the "failure" of plea bargaining. We show in a model of asymmetric information that a public prosecutor facing re-election takes cases to the courtroom to signal quality even when her welfare (absent retention motivation) is always higher from plea bargaining.
\end{abstract}

Keywords: Plea Bargaining; Re-Election; Prosecutor

\section{Introduction}

Trials in the United States are expensive and time consuming. The average cost of a trial is $\$ 10,000$ per day. ${ }^{1}$ However, pretrial bargaining is an available option to save on such costs. Not all disputes, though, are plea bargained. We ask whether there are incentives for cases to be taken to trial even when both prosecutor and defendant know that plea bargaining is efficient. We focus on the incentives of local prosecutors who in the US handle 95\% of all criminal cases (Simmons [1]. Further, in forty-seven states the chief prosecutor is elected (Perry [2]). We argue that a possible explanation for having trials when plea bargaining is efficient is asymmetric information regarding the quality of the public prosecutor. Specifically, it is her desire to be retained in office that leads her to signal her quality by using trials. We show in a simple theoretical model that (absent her retention motivation) even if bargaining is preferable to the prosecutor and for welfare there exist equilibria where trials occur. Convictions act as a signal to the voting public since high-quality prosecutors are better able to obtain them. ${ }^{2}$ We also show that there are environments where total welfares, even after incorporating future benefits of effecttively identifying highly capable prosecutors, are reduced.

\footnotetext{
${ }^{1}$ The 7th pwr.wordpress.com/category/plea-bargain/.

${ }^{2}$ There exists evidence that for state-level elections convictions is an important variable covered by media (Wright [3]) and in a theoretical model retention incentives are shown to influence the investigation decision by prosecutors (Gordon and Huber [4]) who recommend making retention based on convictions.
}

This provides a new explanation for the failure of plea bargaining. A variety of reasons have been provided for its effectiveness: resource conservation (Landes [5]), insurance (Grossman and Katz [6]; Bjerk [7]), and screening (Baker and Mezzetti, [8]; Bjerk [9]; Grossman and Katz [6]; Reinganum, [10,11]). There are two existing explanations for its failure. First, individuals make mistaken assessments. This comes from errors (Priest and Klein [12]) or optimism (Shavell [13]). Second, asymmetric information related to the trial creates a barrier. It may be on the likelihood of success (Bebchuk [14]), costs and damages (Bebchuk [15]), or risk preferences (Farmer and Pecorino [16]) or a combination of optimism and asymmetric information (Farmer and Pecorino [17]). Ancelot and Delacote [18] consider the plea outcome under different fee schemes for prosecutors and an altruistic defense attorney.

We contribute to the explanations for the failure of plea bargaining by introducing retention motivations of prosecutors. There are other papers on plea bargaining as a signal (Reinganum $[8,9]$ ), but they are not about its role of signaling prosecutorial quality. There is evidence that elected prosecutors obtain more convictions (Rasmusen, Raghav and Ramseyer [19]) and those facing contested elections increase their use of jury trials (Bandyopadhyay and McCannon [20]), consistent with our theory that trials are a signal of quality. ${ }^{3}$

\footnotetext{
${ }^{3}$ There are also papers (Boylan [21], Boylan and Long [22]) which show that prosecutors use experience in trials as a career advancement mechanism, i.e. to improve their future payoffs.
} 


\section{Model}

There are two periods. In the first, there is an incumbent of unknown quality who has to decide how to handle cases. She may be one of two types $q \in\{H, L\}$. She is high quality with probability $\gamma \in(0,1)$. Let $\theta \in\left[\theta, \theta_{M}\right]$ denote the strength of evidence, she has against the defendant in any given case ${ }^{4}$. Observing $\theta$ for a case, she may either take it to trial or plea bargain. Assume a large number of cases come up in the first period, which may be thought of as a term in office.

Denote $s$ as the sanction if successful in the courtroom. It makes no difference for our analysis whether $s$ is a constant or $s=s(\theta)$ with $\frac{\mathrm{d} s}{\mathrm{~d} \theta}>0$. With judicial discretion, parole, and appeals this may be thought of as the expected sanction conditional on conviction. The probability the prosecutor is successful depends on the quality of the prosecutor and the evidence. A prosecutor of quality $q$ wins at trial with probability $p_{q}(\theta)$. Assume $1>p_{H}(\theta)>p_{L}(\theta)>0 \quad \forall \theta$ and $\frac{\mathrm{d} p_{q}}{\mathrm{~d} \theta}>0 \quad \forall q$. If she takes the case to trial, a cost $c>0$ is experienced. Denote $b(\theta, c)$ as the plea agreement with $\frac{\partial b}{\partial \theta}>0$ and $\frac{\partial b}{\partial c}<0$. As the prosecutor type is private information to the defendant, sanctions can not be conditioned on type though it can be shown (calculations available on request) that there are no substantive changes in the equilibrium analysis if better prosecutors can negotiate better plea agreements, i.e. if $b$ increases with $q$. One would expect that the evidence affects the bargain since it determines the size of the surplus to be negotiated over. Similarly, the cost incurred reduces this surplus; and therefore, presumably affects the plea bargaining outcome.

\subsection{Welfare}

Denote $w(z)$ as welfare from a case resulting in $z$, either $z=b(\theta, c), s(\theta)$, or 0 depending on whether a case is plea bargained, taken to trial and won or taken to trial and lost. Thus, expected welfare from a case at trial is $E w(\theta)=p_{q}(\theta) w(s(\theta))+\left(1-p_{q}(\theta)\right) w(0)-c .^{5}$ To make things as stark as possible, we consider a situation where plea bargaining is always efficient, i.e. we con-

\footnotetext{
${ }^{4}$ We assume that the decision to file charges has already been made. Thus, only cases strong enough to file charges are considered.

${ }^{5}$ One may presume that $w(z)$ incorporates wrongful convictions and acquittals along with $\theta$ incorporating the quality of the defense.
}

sider an environment where

$$
\begin{aligned}
w(b(\theta, c))> & p_{q}(\theta) w(s(\theta)) \\
& +\left(1-p_{q}(\theta)\right) w(0)-c \quad \forall \theta \forall q .
\end{aligned}
$$

Thus, plea bargaining is better for society for every case, even for a high-quality prosecutor who is more successful. We assume that the plea bargain is a fraction of the expected penalty at trial which seems a natural assumption. ${ }^{6}$ One way to rationalize, this is to assume discounting; trials are time consuming so if the expected penalty is $p_{q}(\theta) s$, the defendant is indifferent to that and an immediate sanction of $\delta p_{q}(\theta) s$ with $0<\delta<1 .^{7}$ Any $b(\theta, c)=\delta p_{q}(\theta) s$ implies that

$$
\begin{aligned}
& w(b(\theta, c))-p_{q}(\theta) w(s(\theta))-\left(1-p_{q}(\theta)\right) w(0) \\
& >w\left(b\left(\theta^{\prime}\right)\right)-p_{q}\left(\theta^{\prime}\right) w\left(s\left(\theta^{\prime}\right)\right)-\left(1-p_{q}\left(\theta^{\prime}\right)\right) w(0)
\end{aligned}
$$

for $\theta^{\prime}>\theta \quad \forall q$ along with $\frac{\mathrm{d} w}{\mathrm{~d} z}>0$. Thus, the gap between the value of plea bargaining and the expected welfare from trial diminishes with better evidence.

Denote $W_{q}$ as the first period expected welfare. Let $F:\left[0, \theta_{M}\right] \rightarrow[0,1]$ be the distribution function in which the evidence for each case is (independently) drawn. Assume a large number of cases arise in the term so that the expected welfare from a case equals the average welfare generated from all cases over the term. Thus, first-period welfare equals the expected welfare from a case. Hence, if a prosecutor chooses to take every case to trial where $\theta>\psi$ and plea those with $\theta<\psi$, then

$$
\begin{aligned}
W_{q}= & \int_{0}^{\psi} w(b(\theta, c)) \mathrm{d} F(\theta)+\int_{\psi}^{\theta_{M}}\left[p_{q}(\theta) w(s(\theta))\right. \\
& \left.+\left(1-p_{q}(\theta)\right) w(0)-c\right] \mathrm{d} F(\theta) .
\end{aligned}
$$

Finally, if her type is known, second-period welfare is $V_{q}$, while it is $E V=\gamma V_{H}+(1-\gamma) V_{L}$ if the type is not, where $V_{H}>V_{L}$. Hence, if a prosecutor's type becomes known and she is re-elected, second period welfare is $V_{q}$ while if she is replaced we assume that the person who replaces her has an expected quality $E V$. The interpretation is simple, society benefits from a more capable prosecutor as a more capable prosecutor can dispense society's objectives more efficiently, i.e. we assume a positive correlation between a prosecutor's ability at trial

${ }^{6}$ In fact, Black's Law Dictionary defines plea bargaining as "the process whereby the accused and the prosecutor in a criminal case work out a mutually satisfactory disposition of the case subject to court approval It usually involves the defendant's pleading guilty to a lesser offense or to only one or some of the counts of a multi-count indictment in return for a lighter sentence than that possible for the graver charge".

${ }^{7} \mathrm{~A}$ similar result can be obtained with optimism bias on the part of the defendant. 
and her efficiency in other aspects of her work. ${ }^{8}$

\subsection{Asymmetric Information}

Suppose voters do not know the incumbent's type. While it is best if every case is plea bargained, with private information a retention agent cannot distinguish between high and low-quality incumbents. If some cases are taken to trial, success in the courtroom would be a reasonable metric to use to evaluate her since the types differ in their ability to obtain a conviction. We are interested in establishing whether there exist environments in which wastefully cases are taken to trial for the purpose of being re-elected.

The preference of the prosecutor needs to be considered. We propose the most favorable preferences for welfare. Specifically, assume the utility she derives is proportional to the welfare, or rather, $u(z)=\alpha w(z)$ for $\alpha>0$. Thus, absent motivation to be retained she is interested in "dispensing justice". Additionally, she receives a bonus from being retained, $R$. Assume the bonus is independent of the prosecutor's quality. If a prosecutor does take cases to trial, then she takes those more likely to win and where there is less welfare lost. Hence, if she proceeds to trial when and only when $\theta>\psi$, then her expected utility if not retained is

$$
\begin{aligned}
E u_{q}= & \int_{0}^{\psi} u(b(\theta, c)) \mathrm{d} F(\theta)+\int_{\psi}^{\theta_{M}}\left[p_{q}(\theta) u(s(\theta))\right. \\
& \left.+\left(1-p_{q}(\theta)\right) u(0)-c\right] \mathrm{d} F(\theta) .
\end{aligned}
$$

If she is retained, her utility is $E u_{q}+R$. Hence, absent the retention motivation the prosecutor is interested in bargaining every case. We solve for the separating equilibria that arise as Perfect Bayesian equilibria. ${ }^{9}$

\section{Separating Equilibrium}

Suppose the incumbent is retained if and only if the number of convictions achieved is greater than or equal to a threshold, $n^{*}$, or rather, if ${ }^{10}$

\footnotetext{
${ }^{8}$ The model assumes both types receive the same outcome with plea bargaining and that it is efficient. Hence, one might expect voters to be indifferent between the types, $V_{H}=V_{L}$. However, there is a positive benefit to having a higher quality prosecutor in office as we assume he is more efficient in all other related prosecutorial activities which we have not explicitly modeled but is captured by $V_{H}$ or $V_{L}$. Moreover, it can be shown that the results remain if $b_{H}(\theta, c)>b_{L}(\theta, c)$ (so long as (1) continues to hold). The assumption of $V_{H}>V_{L}$ can thus be justified.

${ }^{9}$ Pooling equilibria are not considered here since our objective is to establish the existence of equilibria where the high-quality prosecutors behave wastefully to be distinguished and retained.

${ }^{10}$ We choose to define $n_{q}$ on the expected number of convictions.

With the assumption that there are a large number of cases in a term, this does not impose any problems for the analysis.
}

$$
n_{q}=\int_{\psi}^{\theta_{M}} p_{q}(\theta) \mathrm{d} F(\theta) \geq n^{*} .
$$

The question here is whether there exist equilibria where $n^{*}>0$, i.e. we get inefficient trials even when both parties would have preferred to plea.

If the incumbent does not act to be retained, then since utility is proportional to welfare she chooses to plea all cases. Thus, retention is preferable if

$$
\begin{aligned}
& \int_{\psi_{q}^{*}}^{\theta_{M}}\left[p_{q}(\theta) u(s(\theta))+\left(1-p_{q}(\theta)\right) u(0)-c\right] \mathrm{d} F(\theta) \\
& +\int_{0}^{\psi_{q}^{*}} u(b(\theta, c)) \mathrm{d} F(\theta)+R \geq \int_{0}^{\theta_{M}} u(b(\theta)) \mathrm{d} F(\theta),
\end{aligned}
$$

where $\psi_{q}^{*}$ is the value of $\psi$ which results in $n_{q}=n^{*}$. This reduces to

$$
\begin{gathered}
R \geq \int_{\psi}^{\theta_{M}}\left[u(b(\theta, c))-p_{q}(\theta) u(s(\theta))\right. \\
\left.-\left(1-p_{q}(\theta)\right) u(0)+c\right] \mathrm{d} F(\theta) .
\end{gathered}
$$

where $\psi=\psi_{q}^{*}$. Denote $\phi_{q}$ as the value of $\psi$ where (6) holds with equality. Define $v_{q}$ as the value of $n_{q}$ that arises if $\psi=\phi_{q}$.

For a separating equilibrium to exist only a high-quality prosecutor is willing to achieve the required threshold. Hence, if $\theta>\phi_{H}$ and $\theta<\phi_{L}$, then (6) holds for a high-quality, but not for a low-quality prosecutor. Thus, we are left only to verify that there exists an $n^{*}$ where both hold.

First, since $p_{H}(\theta)$ is greater than $p_{L}(\theta)$ the expected welfare loss to proceeding to court is less. In other words, if both types use the same cutoff $\psi$, then the RHS of (6) is less for $q=H$. Therefore, it must be that at $\psi=\phi_{L}$, a high-quality prosecutor is still willing to act to be retained. As a result, $\phi_{H}<\phi_{L}$. Consequently, $v_{H}>v_{L}$ so that $\left(v_{L}, v_{H}\right]$ is nonempty.

Proposition 1: There exist separating equilibria where a high-quality prosecutor achieves $n^{*} \in\left(v_{L}, v_{H}\right]$ and is retained, while a low-quality prosecutor engages in plea bargaining in every case and is not retained.

In all separating equilibria, it is the low-quality prosecutor who selects the first-best amount of prosecution, while it is the high-quality prosecutor who is engaging in an excessive number of trials. Furthermore, while the model presented assumes the number of convictions is the metric used to make the retention decision, an equivalent result is obtained if the median voter uses the aggregate sentences obtained by the prosecutor as the metric on which to base her re-election decision.

The final issue to consider is whether the separating equilibria are, in fact, worse for total welfare than pleaing all cases. If the type is identified, then the second-period welfare is $V_{H}$ if $q=H$ and $E V$ if $q=L$. Total 
welfare is less in a separating equilibrium if

$$
\begin{aligned}
V_{H}-V_{L} \leq & (1-\gamma) \int_{\psi_{q}^{*}}^{\theta_{M}}\left[w(b(\theta, c))-p_{H}(\theta) w(s(\theta))\right. \\
& \left.-\left(1-p_{H}(\theta)\right) w(0)+c\right] \mathrm{d} F(\theta) .
\end{aligned}
$$

Proposition 2: If the cost of trial is substantial, the likelihood of the replacement being low quality is great, the probability of success in trial is small, or the gain to having a high-quality prosecutor in office is small relative to the actions of a low-quality incumbent, i.e. (7) holds, then the separating equilibria generate a lower total welfare (in terms of median voter's utility) than the outcome of plea bargaining every case.

In this note, we have analyzed a stark environment, viz. one where in each case, welfare generated from plea bargaining is greater than from going to trial ${ }^{11}$. We show that unlike a standard bargaining environment where efficient outcomes are obtained, the asymmetric information on the skills of the incumbent prosecutor who wishes to be retained leads to some cases being taken to trial. The voters, due to the informational constraint, cannot take into account all relevant payoff components. Thus, this provides an alternate explanation for why all cases are not plea bargained. The result calls into question the effectiveness of popular elections to select and retain public prosecutors. Additional analysis is needed to investigate whether other metrics can be used to provide proper incentives and whether alternative institutions, such as appointments, do not suffer from similar distortions. These, though, are reserved for future investigation.

\section{REFERENCES}

[1] R. Simmons, "Election of Local Prosecutors," ElectionLaw@Moritz, moritzlaw.osu.edu/electionlaw/. 2004.

[2] S.W. Perry, "Prosecutors in State Courts," United States Department of Justice, 2005.

[3] R. F. Wright, "How Prosecutor Elections Fail Us," Ohio State Journal of Criminal Law, Wake Forest University, Vol. 6, 2009, pp. 649-660.

[4] S. C. Gordon and G. A. Huber, "Citizen Oversight and the Electoral Incentives of Criminal Prosecutors,” American Journal of Political Science, Vol. 46, No. 2, 2002, pp. 334-51. http://dx.doi.org/10.2307/3088380

[5] W. M. Landes, "An Economic Analysis of the Courts," Journal of Law and Economics, Vol. 4, No. 1, 1971, pp.

\footnotetext{
${ }^{11}$ Clearly, in the real world there are gains from taking cases to trial; not least in aiding the development of case law. We have chosen to ignore this to present the starkest environment to show the distortions that signaling causes. However, even with it being optimal to take some cases to trial signaling would still distort the mix by leading to more cases being take to trial than is socially optimal.
}

61-108. http://dx.doi.org/10.1086/466704

[6] G. M. Grossman and M. L. Katz, "Plea Bargaining and Social Welfare," American Economic Review, Vol. 73, No. 4, 1983, pp. 749-757.

[7] D. Bjerk, "On the Role of Plea Bargaining and the Distribution of Sentences in the Absence of Judicial System Frictions," International Review of Law and Economics, Vol. 28, No. 1, 2008, pp. 1-7. http://dx.doi.org/10.1016/j.irle.2007.12.005

[8] S. Baker and C. Mezzetti, "Prosecutorial Resources, Plea Bargaining, and the Decision to Go to Trial," Journal of. Law Economics and Organization, Vol. 17, No. 1, 2001, pp. 149-167. http://dx.doi.org/10.1093/jleo/17.1.149

[9] D. Bjerk, “Guilt Shall Not Escape or Innocence Suffer? The Limits of Plea Bargaining When Defendant Guilt Is Uncertain," American Law Economics Review, Vol. 9, No. 2, 2007, pp. 305-329. http://dx.doi.org/10.1093/aler/ahm010

[10] J. F. Reinganum, "Plea Bargaining and Prosecutorial Discretion,” American Economic Review, Vol. 78, No. 4, 1988, pp. 713-728.

[11] J. F. Reinganum, "Sentence Guidelines, Judicial Discretion, and Plea Bargaining," RAND Journal of Economics, Vol. 31, No. 1, 2000, pp. 62-81.

[12] G. L. Priest and B. Klein, "The Selection of Disputes for Litigation,” Journal of Legal Studies, Vol. 13, No. 1, 1984, pp. 1-55. http://dx.doi.org/10.1086/467732

[13] S. Shavell, "Suit, Settlement, and Trial: A Theoretical Analysis under Alternative Methods for the Allocation of Legal Costs,” Journal of Legal Studies, Vol. 11, No. 1, 1982, pp. 55-81. http://dx.doi.org/10.1086/467692

[14] L. A. Bebchuk, "Litigation and Settlement under Imperfect Information,” RAND Journal of Economics, Vol. 15, No. 3, 1984, pp. 404-415.

[15] L. A. Bebchuk, "Suing Solely to Extract a Settlement Offer,” Journal of Legal Studies, Vol. 17, No. 2, 1988 pp. 437-450. http://dx.doi.org/10.1086/468136

[16] A. Farmer and P. Pecorino, "Pretrial Negotiations with Asymmetric Information on Risk Preferences," International Review of Law and Economics, Vol. 14, No. 3, 1994, pp. 273-281. http://dx.doi.org/10.1016/0144-8188(94)90043-4

[17] A. Farmer and P. Pecorino, "Pretrial Bargaining with Self-Serving Bias and Asymmetric Information,” Journal of Economic Behavior and Organization, Vol. 48, No. 2, 2002, pp. 163-176. http://dx.doi.org/10.1016/S0167-2681(01)00236-0

[18] L. Ancelot and P. Delacote, "Prosecutor and Lawyers in Plea Bargaining with Complete Information,” Economics Bulletin, Vol. 29, No. 3, 2009, pp. 1925-1932.

[19] E. Rasmusen, M. Raghav and M. Ramseyer, "Convictions versus Conviction Rates: The Prosecutor's Choice,” American Law and Economics Review, Vol. 11, No. 1, 2009, pp. 47-78. http://dx.doi.org/10.1093/aler/ahp007

[20] S. Bandyopadhyay and B. McCannon, "The Effect of the 
Election of Prosecutors on Criminal Trials," Working Paper, 2010.

[21] R. T. Boylan, "What Do Prosecutors Maximize? Evidence from Careers of US Attorneys," American Law Economics Review, Vol. 7, No. 2, 2005, pp. 379-402. http://dx.doi.org/10.1093/aler/ahi016
[22] R. T. Boylan and C. Long, "Salaries, Plea Rates, and the Career Objectives of Federal Prosecutors," Journal of. Law and Economics, Vol. 48, No. 2, 2005, pp. 27-51. http://dx.doi.org/10.1086/429854 